\title{
Hyperconjugative Stabilization of Silicenium Ions: Kinetics of Hydride Abstractions from $\beta$-Element Substituted Silanes ${ }^{\perp}$
}

\author{
Nils Basso, ${ }^{\dagger}$ Solvig Görs, $¥$ Eckhard Popowski, $\ddagger$ and Herbert Mayr, 8 \\ Contribution from the Institut für Chemie, Medizinische Universität zu Lübeck, D-23562 Lübeck, \\ Germany, and the Fachbereich Chemie, Universität Rostock, D 18055 Rostock, Germany
}

Received November 30, 1992. Revised Manuscript Received March 1, 1993

\begin{abstract}
Rates of hydride abstractions from $\beta$-silyl-, $\beta$-germyl-, and $\beta$-stannyl-substituted silanes $\left[\mathrm{HSiMe}_{2}\left(\mathrm{CH}_{2}-\right.\right.$ $\left.\mathrm{MMe}_{3}\right), \mathrm{M}=\mathrm{Si}, \mathrm{Ge}, \mathrm{Sn}$ ] and related compounds by diarylcarbenium ions have been measured. The intermediate silicenium ions, produced in the rate-determining step, are stabilized by hyperconjugation, but the effects are much smaller than in comparable carbenium ions.
\end{abstract}

\section{Introduction}

The stabilization of carbenium ions by $\beta$-silyl, $\beta$-germyl, and $\beta$-stannyl groups has been derived from solvolysis rates of $\beta$-element-substituted alkyl derivatives, ${ }^{1}$ rates of electrophilic addition to allyl- ${ }^{2}$ and vinylelement ${ }^{3}$ compounds, and rates of hydride abstraction from element-substituted alkanes. ${ }^{4-6}$

Traylor investigated hydride abstractions from tetraethylelement compounds by the trityl cation. ${ }^{4 b}$ The rate was found to strongly depend on the nature of the metal, indicating increasing hyperconjugative stabilization of carbenium ions in the order $\mathrm{Si}-\mathrm{C}<\mathrm{Ge}-\mathrm{C}<\mathrm{Sn}-\mathrm{C}<\mathrm{Pb}-\mathrm{C}$ (Table I). Similar effects have been discussed for the interaction between $\sigma\left(\mathrm{Si}-\mathrm{CH}_{2}\right)$ and the singly-occupied p-orbital at germanium in germyl radicals $\mathrm{Me}_{3^{-}}$ $\mathrm{SiCH}_{2}\left(\mathrm{Me}_{2}\right) \mathrm{Ge}^{\circ}$. ${ }^{7}$ The comparison with the rate of hydride abstraction in cycloheptatriene shows that the stabilization of

¿Dedicated to Professor R. P. Kreher on the occasion of his 60 th birthday.

Medizinische Universität zu Lübeck.

IUniversitắt Rostock.

INew address: Institut für Organische Chemie, Technische Hochschule Darmstadt, D-64287 Darmstadt, Germany.

(1) (a) Sommer, L. H.; Baughman, G. A. J. Am. Chem. Soc. 1961, 83, 3346. (b) Cook, M. A.; Eaborn, C.; Walton, D. R. M. J. Organomet. Chem. 1970, 24, 301. (c) Lambert, J. B.; Wang, G.-t.; Finzel, R. B.; Teramura, D. H. J. Am. Chem. Soc. 1987, 109, 7838. (d) Lambert, J. B.; Wang, G.-t. Tetrahedron Lett. 1988, 29, 2551. (e) Lambert, J. B.; Wang, G.-t.; Teramura D. H. J. Org. Chem. 1988, 53, 5422. (f) Lambert, J. B.; Wang, G.-t. J. Phys. Org. Chem. 1988, l, 169. (g) Lambert, J. B.; Chelius, E. C. J. Am. Chem. Soc. $1990,112,8120$.

(2) (a) Hagen, G.; Mayr, H. J. Am. Chem. Soc. 1991, 113, 4954. (b) Mayr, H.; Hagen, G. J. Chem. Soc., Chem. Commun. 1989, 91. (c) Mayr, H.; Pock, R. Tetrahedron 1986, 42, 4211. (d) Bartl, J.; Steenken, S.; Mayr, H. J. Am. Chem. Soc. 1991, 113, 7710.

(3) (a) Soderquist, J. A.; Hassner, A. Tetrahedron Lett. 1988, 29, 1899. (b) Cochran, J. C.; Williams, L. E.; Bronk, B. S.; Calhoun, J. A.; Fassberg, J.; Clark, K. G. Organometallics 1989, 8, 804. (c) Hagen, G. Ph.D. Thesis, Medizinische Universităt Lübeck, 1990.

(4) Solution studies: (a) Traylor, T. G.; Koermer, G. S. J. Org. Chem 1981, 46, 3651. (b) Jerkunica, J. M.: Traylor, T. G. J. Am. Chem. Soc. 1971 93, 6278. See also: (c) Davis, D. D.; Jacocks, H. M., III J. Organomet. Chem. 1981, 206, 33.

(5) Gas-phase studies of $\mathrm{R}_{3} \mathrm{Si}^{+}$: (a) Hajdasz, D.; Squires, R. J. Chem. Soc. Chem. Commun. 1988, 1212. (b) Li, X.:Stone, J.A.J. Am. Chem. Soc. 1989, 111, 5586. (c) Ciommer, B.; Schwarz, H. J. Organomet. Chem. 1983, 244, 319. (d) Drewello, T.; Burgers, P. C.; Zummack, W.; Apeloig, Y.; Schwarz, H. Organometallics 1990, 9,1161 .

(6) Theoretical investigations of $\mathrm{R}_{3} \mathrm{Si}^{+}$: (a) Wierschke, S. G.; Chandrasekhar, J.; Jorgensen, W. L. J. Am. Chem. Soc. 1985, 107, 1496. (b) White, J. C.; Cave, R. J.; Davidson, E. R. J. Am. Chem. Soc. 1988, $110,6308$. (c) Ibrahim, M. R.; Jorgensen, W. L. J. Am. Chem. Soc. 1989, 111, 819. (d) Eaborn, C. J. Chem. Soc., Chem. Commun. 1972, 1255. (e) Lambert, J. B. Tetrahedron 1990, 46, 2677. (f) Apeloig, Y. In The Chemistry of Organic Silicon Compounds; Patai, S., Rappoport, Z., Eds.; John Wiley \& Sons: Chichester, 1989; Part 1, p 196. (g) Apeloig, Y. In Heteroatom Chemistry; Block, E., Ed.: VCH-Verlagsgesellschaft: Weinheim 1990; 27.

(7) Mochida, K. Bull. Chem. Soc. Jpn. 1984, 57, 796.
Table I. Rate Constants for the Hydride Transfer from the Organometallic Compounds Et $\mathbf{M}(\mathrm{M}=\mathrm{Si}, \mathrm{Ge}, \mathrm{Sn}, \mathrm{Pb})$ to $\mathrm{Ph}_{3} \mathrm{C}^{+} \mathrm{BF}_{4}-\left(\mathrm{H}_{3} \mathrm{CCN},+29.8^{\circ} \mathrm{C}\right)^{4 \mathrm{~b}}$

\begin{tabular}{lclc}
\hline compd & $k_{2},{ }^{a} \mathrm{~L} \cdot \mathrm{mol}^{-1}{ }^{-\mathrm{s}^{-1}}$ & \multicolumn{1}{c}{ compd } & $k_{2},{ }^{a} \mathrm{~L} \cdot \mathrm{mol}^{-1}{ }^{-\mathrm{s}^{-1}}$ \\
\hline $\mathrm{Et}_{4} \mathrm{Si}$ & $5.7 \times 10^{-8}$ & $\mathrm{Et}{ }_{4} \mathrm{~Pb}$ & $4.9 \times 10^{-1}$ \\
$\mathrm{Et}_{4} \mathrm{Ge}$ & $4.0 \times 10^{-6}$ & cycloheptatriene & $2.1 \times 10^{-1}$ \\
$\mathrm{Et}_{4} \mathrm{Sn}$ & $8.3 \times 10^{-4}$ & & \\
\hline
\end{tabular}

${ }^{a} k_{2}$ per hydrogen.

Table II. Rate Constants for the Reaction of $\mathrm{Ph}_{3} \mathrm{C}^{+} \mathrm{BF}_{4}$ with 1,3-Dimetallopropanes $\mathrm{Me}_{3} \mathrm{M}-\mathrm{CH}_{2} \mathrm{CH}_{2} \mathrm{CH}_{2}-\mathrm{M}^{\prime} \mathrm{Me}_{3}\left(\mathrm{M}, \mathbf{M}^{\prime}=\mathrm{C}\right.$, $\mathrm{Si}, \mathrm{Ge}, \mathrm{Sn}, \mathrm{Pb}$ ) in $\mathrm{H}_{3} \mathrm{CCN}$ at $+30^{\circ} \mathrm{C} 4 \mathrm{e}$

\begin{tabular}{|c|c|}
\hline compd & $k_{2}{ }^{a}, L \cdot \mathrm{mol}^{-1} \cdot \mathrm{s}^{-1}$ \\
\hline $\mathrm{Me}_{3} \mathrm{Si}$ & $6.2 \times 10^{-66}$ \\
\hline $\mathrm{Meg} \mathrm{SI}$. & $1.9 \times 10^{-5}$ \\
\hline $\mathrm{Mes}_{3} \mathrm{Si}$ & $5.9 \times 10^{-4}$ \\
\hline $\mathrm{Me}_{3} \mathrm{St}$ & $1.3 \times 10^{-1}$ \\
\hline $\mathrm{Me}_{3} \mathrm{Ce}_{\mathrm{O}}$ & $1.8 \times 10^{-4}$ \\
\hline$G_{n}$ & $7.1 \times 10^{-3}$ \\
\hline $\mathrm{Me}_{3} \mathrm{Co}$. & $2 \times 10^{-1}$ \\
\hline$M=a^{\circ}$ & $2 \times 10^{-46}$ \\
\hline $\mathrm{Me}_{3} \mathrm{Sn}$, & $4 \times 10^{-2}$ \\
\hline
\end{tabular}

${ }^{a} k_{2}$ per hydrogen. ${ }^{b}$ Solvent: $50 \% \mathrm{CD}_{3} \mathrm{CN}$ in $\mathrm{CD}_{2} \mathrm{Cl}_{2}$.

the $\beta$-lead-substituted carbenium ion $\mathrm{Et}_{3} \mathrm{~Pb}-\mathrm{CH}_{2} \mathrm{CH}_{2}{ }^{+}$is comparable to that of the tropylium ion $\left(\mathrm{p} K_{\mathrm{R}^{+}}=+4.76^{8}\right)$.

Disubstituted alkanes $\mathrm{Me}_{3} \mathrm{M}-\mathrm{CH}_{2} \mathrm{CH}_{2} \mathrm{CH}_{2}-\mathrm{M}^{\prime} \mathrm{Me}_{3}$ (1,3dimetallopropanes, $\mathrm{M}$ or $\mathbf{M}^{\prime}=\mathrm{C}, \mathrm{Si}, \mathrm{Ge}, \mathrm{Sn}, \mathrm{Pb}$ ) react considerably faster with $\mathrm{Ph}_{3} \mathrm{C}^{+4 a}$ (Table II). From the magnitude of the substituent effects it was concluded that bridging of the metal is not important in the transition state.

Recently, we reported rates of hydride abstractions from silanes and derived the effect of various substituents for stabilizing silicenium ions.9a In agreement with related experimental investigations ${ }^{9 b, c}$ and theoretical predictions, ${ }^{6} \pi$-conjugation has been found to be much less effective for silicenium ions than for carbenium ions. ${ }^{9 a}$ Comparison of the hydride abstractions from silanes, germanes, and stannanes showed the decreasing importance of $\pi$-conjugation with increasing size of the central atom.

(8) Ritchie, C. D. Can. J. Chem. 1986, 64, 2239.

(9) (a) Mayr, H.; Basso, N.; Hagen, G. J. Am. Chem. Soc. 1992, 114, 3060. (b) Chojnowski, J.; Fortuniak, W. Stanczyk, W. J. Am. Chem Soc. 1987, 109,7776. (c) Chojnowski, J.; Wilczek, L.; Fortuniak, W.J. Organomet. Chem. 1977, 135, 13. (d) Mayr, H.; Basso, N. Angew. Chem. 1992, 104, 1103; Angew. Chem., Int. Ed. Engl. 1992, 31, 1046. (e) Mayr, H.; Schneider, R.; Schade, C.; Bartl, J.; Bederke, R. J. Am. Chem. Soc. 1990, 112, 4446. 


\section{Scheme I}

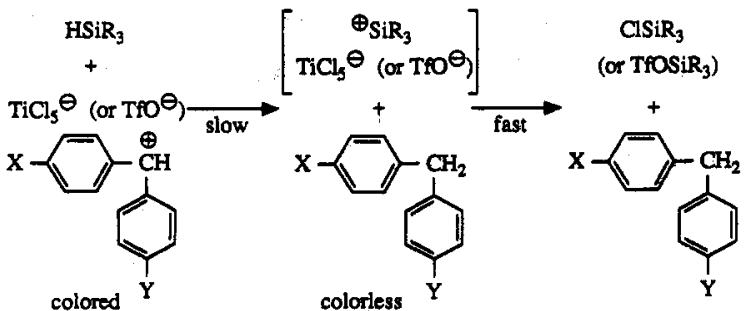

Analogously, hyperconjugation has been calculated to be more important in carbenium ions than in silicenium ions. Thus, at $\mathrm{MP} 2 / 6-31 \mathrm{G}^{*} / / 3-21 \mathrm{G}^{(*)}$ eq 1 is exothermic by $33.1 \mathrm{kcal} \cdot \mathrm{mol}^{-1}$ compared with only $10.3 \mathrm{kcal} \cdot \mathrm{mol}^{-1}$ for eq $2\left(\mathrm{MP3} / 6-31 \mathrm{G}^{*} / /\right.$ $\left.6-31 G^{*}\right) .68$

$$
\mathrm{H}_{3} \mathrm{SiCH}_{2} \mathrm{CH}_{3}+\mathrm{H}_{3} \mathrm{CCH}_{2}^{+} \rightarrow \mathrm{H}_{3} \mathrm{SiCH}_{2} \mathrm{CH}_{2}^{+}+\mathrm{H}_{3} \mathrm{CCH}_{3}
$$

$\mathrm{H}_{3} \mathrm{SiCH}_{2} \mathrm{SiH}_{3}+\mathrm{H}_{3} \mathrm{CSiH}_{2}^{+} \rightarrow \mathrm{H}_{3} \mathrm{SiCH}_{2} \mathrm{SiH}_{2}^{+}+\mathrm{H}_{3} \mathrm{CSiH}_{3}$

We have now studied the kinetics of hydride abstractions from $\beta$-silyl-, $\beta$-germyl-, and $\beta$-stannyl-substituted silanes in order to derive the magnitude of hyperconjugative stabilization in silicenium ions.

\section{Methods}

Colored solutions of mono- and di(p-methoxy)-substituted diphenylcarbenium ions were obtained by addition of the corresponding diarylchloromethanes to solutions of $\mathrm{TiCl}_{4}$ or $\mathrm{Me}_{3} \mathrm{SiOSO}_{2} \mathrm{CF}_{3}$ (TMSOTf) in $\mathrm{CH}_{2} \mathrm{Cl}_{2}$ as described previously. The decay of absorbance upon addition of the silanes was followed photometrically using fiber optics and the work station described earlier. $\%$

\section{Results}

As reported for other silanes, 9 the reactions were found to follow a second-order rate law, first order with respect to silane and first order with respect to carbenium ion, in accord with the reaction mechanism described in Scheme I. Previous work ${ }^{9 \mathrm{a}}$ has shown that the reaction rates are independent of the negative counterions, indicating that these are not involved in the ratedetermining step. In this way, a transition state involving pentacoordinate silicon was excluded, and SET processes were eliminated by studying kinetic isotope effects. Rate-determining formation of silicenium ions has thus been derived, though silicenium ions have not yet been observed as persistent entities in the condensed phase. ${ }^{10}$

In this work most hydride abstractions were carried out with the ( $p$-anisyl)(phenyl)carbenium ion $\left(p-\mathrm{H}_{3} \mathrm{COC}_{6} \mathrm{H}_{4}\right) \mathrm{PhCH}^{+}$in dichloromethane at $-70^{\circ} \mathrm{C}$ (Table III). In some cases, also the less electrophilic bis(p-anisyl)carbenium ion $\left(p-\mathrm{H}_{3} \mathrm{COC}_{6} \mathrm{H}_{4}\right)_{2-}$ $\mathrm{CH}^{+}$has been employed, which proved to be 60 to 117 times less reactive than $\left(p-\mathrm{H}_{3} \mathrm{COC}_{6} \mathrm{H}_{4}\right) \mathrm{PhCH}^{+}$.

(10) (a) Prakash, G. K. S.; Keyaniyan, S.; Aniszfeld, R.; Heiliger, L.; Olah, G. A.; Stevens, R. C.; Choi, H.-K.; Bau, R. J. Am. Chem. Soc. 1987, 109, 5123. (b) Olah, G. A.; Heiliger, L.; Li, X.-Y.; Prakash, G. K. S. J. Am. Chem. Soc. 1990, 112, 5991. (c) Wang, N.; Hwu, J. R.; White, E. H. J. Org Chem. 1991, 56, 471. (d) Eaborn, C. J. Organomet. Chem. 1991, 405, 173. (e) Lickiss, P. D. J. Chem. Soc., Dalton Trans. 1992, 1333. (f) Kira, M. Hino, T.; Sakurai, H. J. Am. Chem. Soc. 1992, 114, 6697. (g) Olah, G. A.; Rasul, G.; Heiliger, L.; Bausch, J.; Prakash, G. K. S. J. Am. Chem. Soc. 1992, $114,7737$.

(11) (a) Taft, R. W., Jr.; Lewis, I. C. J. Am. Chem. Soc. 1958, 80, 2436. (b) Taft, R. W. Jr.; Lewis, I. C. Tetrahedron 1939, 5, 210. (c) Levitt, L. S.; Levitt, B. W. Chem. Ind. (London) 1970, 990 . (d) Lovitt, L. S.; Levitt, B. W. Tetrahedron 1973, 29, 941 . (e) Levitt, L. S.; Widing, H. F. Progr. Phys. Org. Chem. 1976, 12, 119. (f) Reynolds, W.F.; Hamer, G. K.; Bassindale, A. R. J. Chem. Soc., Perkin Trans. II 1977, 971.

(12) Calculated according to eq 3 in: Davis, D. D. J. Organomet. Chem. 1981, 206, 21. See also ref $2 a$.
Table III. Second-Order Rate Constants for the Reactions of Diarylcarbenium Ions with $\beta$-Element-IV-Substituted Silanes in $\mathrm{CH}_{2} \mathrm{Cl}_{2}$ at $-70^{\circ} \mathrm{C}$

\begin{tabular}{lcl}
\hline \multicolumn{1}{c}{ silane } & $\begin{array}{c}\mathrm{X}, \mathrm{Y} \text { from } \\
\left(p-\mathrm{XC}_{6} \mathrm{H}_{4}\right)\left(p-\mathrm{YC}_{6} \mathrm{H}_{4}\right) \mathrm{CH}^{+}\end{array}$ & $\begin{array}{c}k_{2}\left(-70^{\circ} \mathrm{C}\right), \\
\text { L.mol-1.-5 }\end{array}$ \\
\hline $\mathrm{HSiMe}_{2}\left(\mathrm{CH}_{2} \mathrm{CMe}_{3}\right)$ & $\mathrm{OMe}, \mathrm{H}$ & $1.65 \times 10^{2}$ \\
$\mathrm{HSiMe}_{2}\left(\mathrm{CH}_{2} \mathrm{SiMe}_{3}\right)$ & OMe, H & $4.99 \times 10^{2}$ \\
$\mathrm{HSiMe}_{2}\left(\mathrm{CH}_{2} \mathrm{GeMe}_{3}\right)$ & OMe, H & $8.69 \times 10^{2}$ \\
$\mathrm{HSiMe}_{2}\left(\mathrm{CH}_{2} \mathrm{SnMe}_{3}\right)$ & OMe, OMe & $5.82 \times 10^{1}$ \\
& OMe, H & $3.53 \times 10^{3}$ \\
$\mathrm{HSiMe}\left(\mathrm{CH}_{2} \mathrm{SiMe}_{3}\right)_{2}$ & OMe, OMe & 5.89 \\
& OMe, H & $5.12 \times 10^{2}$ \\
$\mathrm{HSi}\left(\mathrm{CH}_{2} \mathrm{SiMe}_{3}\right)_{3}$ & OMe, H & $5.84 \times 10^{1}$ \\
$\mathrm{HSi}\left(\mathrm{CH}_{2} \mathrm{SiMe}_{2}{ }^{n} \mathrm{Bu}\right)_{3}$ & OMe, OMe & $8.34 \times 10^{-1}$ \\
$\mathrm{HSi}\left(\mathrm{CH}_{2} \mathrm{SiMe}_{2} \mathrm{Ph}\right)_{3}$ & OMe, H & $9.79 \times 10^{1}$ \\
& OMe, OMe & $3.29 \times 10^{-1}$ \\
& OMe, H & $3.44 \times 10^{1}$ \\
\hline
\end{tabular}

Scheme II. Influence of the Number of $\beta$-(Trimethylsilyl) Substituents on the Hydride Donation Abilities of the Silanes $\mathrm{HSiMe}_{3-n}\left(\mathrm{CH}_{2} \mathrm{SiMe}_{3}\right)_{n}(n=0-3)$

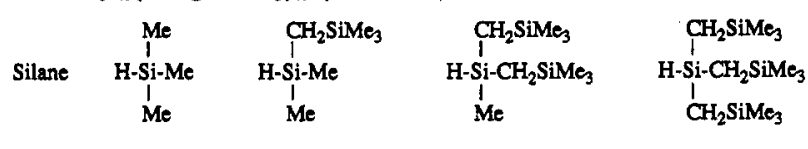

$$
\begin{aligned}
& \begin{array}{lllll}
k_{\text {ral }} & =1.0^{\circ} & 7.8 & 8.0 & 0.9
\end{array}
\end{aligned}
$$

a Reference value: $k_{2}=63.7 \mathrm{~L} \cdot \mathrm{mol}^{-1} \mathrm{~s}^{-1}$.9n

Table IV. Comparison of the Rates of Hydride Transfer from $\beta$-Substituted Silanes $\mathrm{HSi}\left(\mathrm{CH}_{2} \mathrm{SiMe}_{2} \mathrm{R}\right)_{3}$ toward $\left(p-\mathrm{H}_{3} \mathrm{COC}_{6} \mathrm{H}_{4}\right) \mathrm{PhCH}^{+}$with the Substituent Constants $\sigma_{I}(\mathrm{R})^{11}$

\begin{tabular}{ccc}
\hline $\mathrm{HSi}\left(\mathrm{CH}_{2} \mathrm{SiMe}_{2} \mathrm{R}\right)_{3} \mathrm{R}=$ & $k_{\text {rel }}$ & $\sigma_{\mathrm{I}}(\mathrm{R})$ \\
\hline $\mathrm{Ph}$ & $\equiv 1.00$ & +0.100 \\
$\mathrm{Me}$ & 1.70 & -0.046 \\
$\mathrm{n} \mathrm{Bu}$ & 2.85 & -0.054 \\
\hline
\end{tabular}

In order to corroborate that the observed decay of ( $p$ $\left.\mathrm{H}_{3} \mathrm{COC}_{6} \mathrm{H}_{4}\right) \mathrm{PhCH}^{+}$in the presence of $\mathrm{HSiMe}_{2}\left(\mathrm{CH}_{2} \mathrm{SnMe}_{3}\right)$ indeed corresponds to the hydride abstraction from silicon and not to a reaction at another position, we have combined this carbenium ion with the analogous tetrasubstituted silane $\mathrm{Me}_{3}$ $\mathrm{Si}\left(\mathrm{CH}_{2} \mathrm{SnMe}_{3}\right)$. Now, the carbenium ion concentration remained constant within $15 \mathrm{~min}$, while in the corresponding experiment with $\mathrm{HSiMe}_{2}\left(\mathrm{CH}_{2} \mathrm{SnMe}_{3}\right)$ the reaction was complete after approximately $1 \mathrm{~min}$.

\section{Discussion}

The introduction of a $\beta$-trimethylsilyl group in trimethylsilane increases the rate of hydride transfer by a factor of 7.8 (Scheme II). While the second $\beta$-(trimethylsilyl) group has no effect on reactivity, the third depresses the nucleophilicity to give a rate constant almost identical to that of trimethylsilane. These observations can be interpreted by a balance of steric and electronic effects. Whereas electronic effects are dominant when the first substituent is introduced, electronic and steric effects cancel for the second substituent, and steric effects dominate when the third trimethylsilyl group is added.

Table IV shows that a slight reactivity increase occurs as the inductive donation of the substituents at the $\beta$-silicon is growing.

A plot of $\log k_{2}$ versus the $\sigma_{1}$ substituent constants (Figure 1) of the $\beta$-substituents shows a linear correlation for $\mathrm{X}=\mathrm{Cl}$ to $\mathrm{CMe}_{3}\left(\sigma_{\mathrm{I}}=-0.070\right.$ to 0.470$)$. The $\beta$-metal-substituted silanes, however, react faster than expected on the basis of $\sigma_{1}$ (Figure 1) in accord with hyperconjugative stabilization.

Figure 2 shows a linear correlation between the reactivities of $\mathrm{HSiMe}_{2}\left(\mathrm{CH}_{2} \mathrm{MMe}_{3}\right)$ and $\sigma^{+}$of $\mathrm{CH}_{2} \mathrm{MMe}_{3}$, but points for other substituents $\left(\mathrm{CH}_{2}-\mathrm{H}, \mathrm{CH}_{2}-\mathrm{Ph}\right.$, and $\left.\mathrm{CH}_{2}-\mathrm{Cl}\right)$ deviate from this line. The limited range of this correlation is not suprising, as $\sigma^{+}$ 


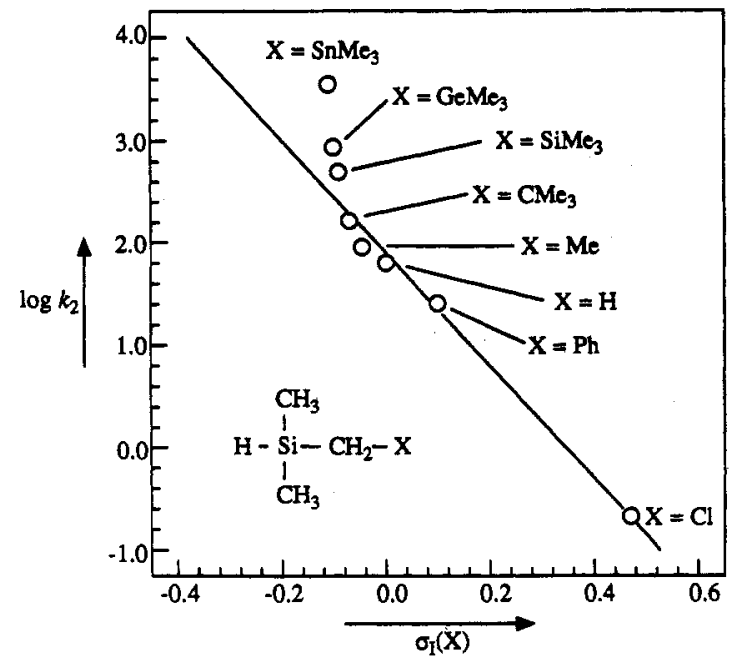

Figure 1. Correlation between the reactivities of the silanes HSi$\mathrm{Me}_{2}\left(\mathrm{CH}_{2} \mathrm{X}\right)$ (toward $\left(\rho-\mathrm{H}_{3} \mathrm{COC}_{6} \mathrm{H}_{4}\right) \mathrm{PhCH}^{+}, \mathrm{CH}_{2} \mathrm{Cl}_{2},-70^{\circ} \mathrm{C}$ ) with the $\sigma_{1}$ values of $\mathrm{X}^{11}(\rho=-5.24, r=0.998)$. Regression analysis was made without $\mathrm{X}=\mathrm{SiMe}_{3}, \mathrm{GeMe}_{3}$, and $\mathrm{SnMe}_{3}$; the $k_{2}$ values for $\mathrm{X}=\mathrm{Cl}, \mathrm{Ph}$, $\mathrm{H}$, and $\mathrm{Me}$ were taken from ref $9 \mathrm{a}$.

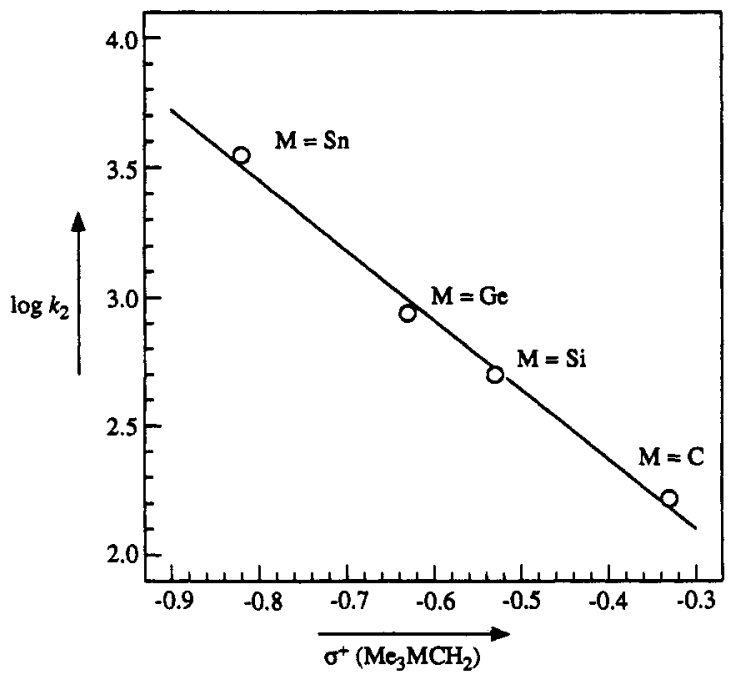

Figure 2. Correlation of the reactivities of the $\beta$-element-substituted silanes $\mathrm{HSiMe}_{2}\left(\mathrm{CH}_{2} \mathrm{MMe}_{3}\right)(\mathrm{M}=\mathrm{C}, \mathrm{Si}, \mathrm{Ge}, \mathrm{Sn})$ toward $\left(\rho-\mathrm{H}_{3} \mathrm{CO}\right.$ $\left.\mathrm{C}_{6} \mathrm{H}_{4}\right) \mathrm{PhCH}^{+}\left(\mathrm{CH}_{2} \mathrm{Cl}_{2},-70^{\circ} \mathrm{C}\right)$ with Davis' $\sigma^{+}$substituent constants ${ }^{12}$ $(\rho=-2.76, r=0.994)$.

values also are not generally suitable for describing the effects of substituents directly attached to carbenium centers. ${ }^{13}$

The absolute value of the slope in Figure 2 shall, therefore, not be overinterpreted, but it can be used for comparison with the effects of the substituents $\mathrm{CH}_{2} \mathrm{MMe}_{3}$ on other reactions. As the slope of this correlation $(\rho=-2.76)$ is considerably smaller than in the analogous plot of $\log k$ values versus $\sigma^{+}\left(\mathrm{CH}_{2} \mathrm{MMe}_{3}\right)$ for hydride abstractions from the tetraethylelement compounds listed in Table $I(\rho=13.8), 4 b, c$ it is concluded that $\sigma-\pi$ interaction is considerably weaker in the transition state of hydride abstractions yielding silicenium ions than in the transition state yielding carbenium ions (Scheme III). This is probably a result of poorer orbital overlap for silicon than for carbon and the reluctance of silicon to participate in multiple bonding. 61,8 An analogous dependence of the rate constants on $\sigma^{+}$of $\mathrm{CH}_{2} \mathrm{MR}_{3}$ has been observed for the attack of benzhydryl cations at allylelement compounds, which also produces $\beta$-element-stabilized carben-

(13) (a) Koshy, K. M.; Roy, D.; Tidwell, T. T. J. Am. Chem. Soc. 1979, 101, 357. (b) Chwang, W. K.; Knittel, P.; Koshy, K. M.; Tidwell, T. T. J. Am. Chem. Soc. 1977, 99, 3395. (c) Oyama, K.; Tidwell, T. T. J. Am. Chem Soc. 1976, 98, 947. (d) Nowlan, V. J.; Tidwell, T. T. Acc. Chem. Res. 1977, 10,252 .
Scheme III. Reaction Constants $\rho$ for Reactions with Rate-Limiting Formation of a $\beta$-Stabilized Cationic Center

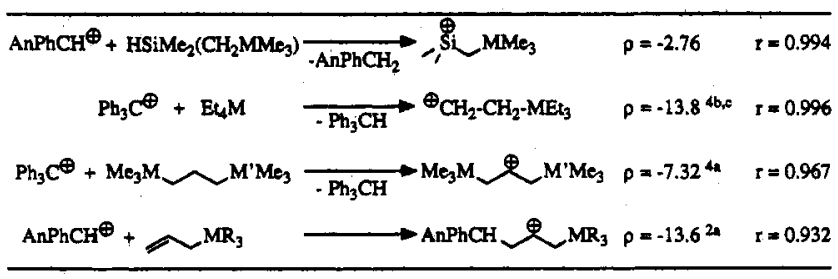

$\mathrm{M}, \mathrm{M}^{\prime}=\mathrm{C}, \mathrm{Si}, \mathrm{Ge}, \mathrm{Sn} ; \mathrm{R}=\mathrm{Cl}, \mathrm{Ph}, \mathrm{Me},{ }^{\mathrm{n}} \mathrm{Bu}$.

ium ions ( $\rho=-13.6$, Scheme III). A smaller $\rho$ value is calculated, however, when $\log k$ for the hydride abstractions from 1,3dimetallopropanes is plotted against $\sum \sigma^{+}\left(\mathrm{CH}_{2} \mathrm{MMe}_{3}\right)$ ( $\rho=$ $-7.32) .4 a$

\section{Conclusion}

All observations concur that hyperconjugation is effective for stabilizing silicenium ions, but the magnitude of this effect is considerably smaller than in comparable carbenium ions.

\section{Experimental Section}

Details of the kinetic procedure and preparations for the carbenium precursors have been published elsewhere. 90 The organoelement compounds have been synthesized according to Popowski. ${ }^{14}$ For $\mathrm{HSiMe}_{2} \mathrm{CCH}_{2-}$ $\mathrm{GeMe}_{3}$ ) the published procedure has been modified by using THF as the solvent for $\mathrm{Me}_{3} \mathrm{GeCl}$. In this way, the yield of side products [ $\mathrm{HSiMe}_{2}\left(\mathrm{CH}_{2}-\right.$ $\left.\left.\mathrm{SiMe}_{3}\right)\right]$ could be reduced.

Dimethyl((trimethylgermyl)methyl)silane. A solution of (bromomethyl)dimethylsilane $(16.0 \mathrm{~g}, 0.104 \mathrm{~mol})$ in ether $(50 \mathrm{~mL})$ was added dropwise to a suspension of magnesium turnings $(2.80 \mathrm{~g}, 0.115 \mathrm{~mol})$ in ether $(50 \mathrm{~mL})$ in an argon atmosphere. The solution of the Grignard reagent was decanted from the magnesium, and the yield was determined by acidimetric titration ( $99 \%$ ). Next, $70 \mathrm{~mL}$ of the etheral solution of (dimethylsilyl)methylmagnesium bromide $(0.070 \mathrm{~mol})$ thus obtained was added dropwise to a solution of $\mathrm{Me}_{3} \mathrm{GeCl}(10.0 \mathrm{~g}, 0.065 \mathrm{~mol})$ in tetrahydrofuran $(70 \mathrm{~mL})$. The mixture was stirred for $4 \mathrm{~h}$ at $35^{\circ} \mathrm{C}$, kept at ambient temperature for $15 \mathrm{~h}$, and then bydrolyzed with an aqueous $\mathrm{NH}_{4} \mathrm{Cl}$ solution (20\%). The organic layer was separated, and the aqueous layer was extracted with ether. After the combined organic layers were washed with $\mathrm{NaHCO}_{3}$ solution and water and dried over $\mathrm{CaCl}_{2}$, and the solvents evaporated, the mixture was distilled over a $10-\mathrm{cm}$ Vigreux column to give $\mathrm{HSiMe}_{2}\left(\mathrm{CH}_{2} \mathrm{GeMe}_{3}\right)\left(4.74 \mathrm{~g}, 38 \%\right.$ ) with bp $130^{\circ} \mathrm{C}$ (lit. ${ }^{14} \mathrm{bp}$ $\left.134-135{ }^{\circ} \mathrm{C}\right)$. GC analysis indicated a purity of $>99 \%$. ' $\mathrm{H}-\mathrm{NMR}$ $\left(\mathrm{CCl}_{4}\right): \delta-0.18\left(\mathrm{CH}_{2}\right), 0.09\left(\mathrm{SiCH}_{3}\right), 0.19\left(\mathrm{GeCH}_{3}\right), 4.05(\mathrm{SiH}){ }^{29} \mathrm{Si}-$ $\mathrm{NMR}\left(\mathrm{CDCl}_{3}\right): \delta-16.03, J\left({ }^{29} \mathrm{Si}-\mathrm{H}\right)=181.0 \mathrm{~Hz}, \mathrm{SiMe}_{4}$ reference. Mass spectrum (70 eV): $m / 2$ (rel intensity) $191\left(2.6 \%, \mathrm{M}^{+}-\mathrm{H}\right), 177(92.9 \%$, $\left.\mathrm{M}^{+}-\mathrm{CH}_{3}\right), 119\left(28.5 \%, \mathrm{Me}_{3} \mathrm{Ge}^{+}\right), 73\left(100 \%, \mathrm{Me}_{3} \mathrm{Si}^{+}\right)$. For IR data see ref 14.

Dimethyl(neopentyl)silane. Neopentyl bromide and lithium were combined according to published procedures ${ }^{15}$ to give neopentyl lithium in 28 and $29 \%$ yield (by Gilman titration ${ }^{16}$ ), respectively. A solution of neopentyl lithium $(50 \mathrm{mmol})$ in $n$-hexane $(100 \mathrm{~mL})$ was added dropwise to a solution of chlorodimethylsilane $(4.26 \mathrm{~g}, 45 \mathrm{mmol})$ in ether $(50 \mathrm{~mL}$, purified by distillation over $\mathrm{Na}$ and $\mathrm{Ph}_{2} \mathrm{CO}$ ), which was cooled in an ice bath (15 min, Ar atmosphere). The mixture was then heated under reflux for $5 \mathrm{~b}$ and worked up as described above to give $40-50 \%$ of $\mathrm{HSiMe}_{2}\left(\mathrm{CH}_{2} \mathrm{CMe}_{3}\right)(2.35-2.93 \mathrm{~g})$ with bp $110-112^{\circ} \mathrm{C}$ (lit. ${ }^{17}$ bp 110.2 ${ }^{\circ} \mathrm{C}$ ). A contamination (probably 2,2,5,5-tetramethylhexane formed during the preparation of neopentyl lithium) could not be removed by distillation. The product has, therefore, been purified by preparative $G C$ (column length $3 \mathrm{~m}, 0 . d .1 \mathrm{~cm} ; 20 \%$ GE SE 30 on chromosorb WAW DMCS, oven temperature $80^{\circ} \mathrm{C}$ ). IR ( $n$-hexane): $\tilde{\nu} 2120.3 \mathrm{~cm}^{-1}(\mathrm{SiH})$. ${ }^{1} \mathrm{H}-\mathrm{NMR}\left(\mathrm{CCL}_{4}\right): \delta 0.07\left(\mathrm{SiCH}_{3}\right), 0.70\left(\mathrm{CH}_{2}\right), 0.99\left(\mathrm{CCH}_{3}\right), 3.99(\mathrm{SiH})$. ${ }^{29} \mathrm{Si}-\mathrm{NMR}\left(\mathrm{CDCl}_{3}\right): \delta-16.03, J\left({ }^{29} \mathrm{Si}-{ }^{\prime} \mathrm{H}\right)=181.0 \mathrm{~Hz}$, SiMe 4 reference.

(14) Popowski, E.; Marekowa, U.; Reiske, T.; Schulz, H.; Kelling, H.; Jancke, H. Z. Anorg. Allg. Chem. 1990, 583, 195.

(15) (a) Beachley, O. T., Jr.; Victoriano, L. Organometallics 1988, 7, 63. (b) Schrock, R. R.; Fellmann, J. D. J. Chem. Soc. 1978, 100, 3359.

(16) Gilman, H.; Cartledge, F. K. J. Organomet. Chem. 1964, 2, 447.

(17) Hetflejs, J.; Mares, F.; Chvalovsky, V. Collect. Czech. Chem. Commun. $1966,31,586$. 
Mass spectrum ( $70 \mathrm{eV}): m / z$ (rel intensity) $130\left(0.25 \%, \mathrm{M}^{+}\right), 129(1.2 \%$, $\left.\mathrm{M}^{+}-\mathrm{H}\right), 115\left(100 \%, \mathrm{M}^{+}-\mathrm{CH}_{3}\right), 73\left(78.7 \%, \mathrm{M}^{+}-\mathrm{CMe}_{3}\right)$.

(Trimethylallyl)(trimethylstanayl)methane. The literature procedure ${ }^{18}$ was improved as follows: trimethylstannyl chloride $(15.0 \mathrm{~g}, 75.3 \mathrm{mmol})$ was dissolved in $50 \mathrm{~mL}$ of ether. A solution of $\mathrm{Me}_{3} \mathrm{SiCH}_{2} \mathrm{Li}(91.2 \mathrm{mmol}$, prepared analogous to the corresponding Grignard reagent in ref 14 in $95 \mathrm{~mL}$ of $n$-hexane) was added dropwise within $15 \mathrm{~min}$ with water-ice cooling (Ar atmosphere). The mixture was stirred for $4 \mathrm{~h}$ at $35^{\circ} \mathrm{C}$, kept at ambient temperature for $15 \mathrm{~h}$, and then worked up as described above. Distillation over a packed column yielded $11.7 \mathrm{~g}\left(62 \%\right.$, bp $164-166^{\circ} \mathrm{C}$, lit. ${ }^{18}$ bp $\left.165-166^{\circ} \mathrm{C}\right)$. ${ }^{1} \mathrm{H}-\mathrm{NMR}\left(\mathrm{CCl}_{4}\right): \delta-0.25\left(\mathrm{CH}_{2}\right), 0.02\left(\mathrm{SiCH}_{3}\right)$,

(18) (a) Papetti, S.; Post, H. W. J. Org. Chem. 1957, 22, 526. (b) Schmidbaur, H. Chem. Ber. 1964, 97, 270.
$0.09\left(\mathrm{SnCH}_{3}\right)$. Mass spectrum $(70 \mathrm{eV}): \mathrm{m} / z$ (rel intensity) 237 (100, $\left.\mathrm{M}^{+}-\mathrm{CH}_{3}\right), 165$ (59.2\%, $\left.\mathrm{Me}_{3} \mathrm{Sn}^{+}\right), 135$ (11.4\%, $\left.\mathrm{MeSn}^{+}\right), 73$ (46.1\%, $\mathrm{Me}_{3} \mathrm{Si}^{+}$).

Acknowledgment. Financial support by the Deutsche Forschungsgemeinschaft and the Fonds der Chemischen Industrie is gratefully acknowledged. We thank Dr. B. Dogan for critical discussions.

Supplementary Material Available: One table with concentrations and rate constants of the kinetic experiments described on Table III ( 3 pages). Ordering information is given on any current masthead page. 